\title{
Money-Price Variability and Asset Prices Volatility: Evidence from India *
}

\author{
DEBA PRASAD RATH \\ dprath@rbi.org.in \\ and \\ RUDRA SENSARMA \\ rsensarma@gmail.com
}

\begin{abstract}
The primary question we seek to address in this paper is does monetary or price stability contribute to asset price stability. The literature in this regard, although rich and growing, is not yet settled with there being still no clear consensus on how one affects the other. Given the evidence of a stabilizing monetary policy and stable headline prices in the post-reform period since the mid -1990s, we argue that Indian economy is a fit case-study to examine such a nexus. Accordingly, we study the impact of money and price variability on asset prices volatility in India. We use data on BSE Sensex to proxy for asset prices and include variability of money supply and wholesale prices as explanatory variables for the volatility of the former. Using monthly data from 1980:04 to 2003:03, and employing alternative methodologies such as GARCH, MA, EWMA to estimate asset prices volatility, we test the hypothesis whether money and price variability have any bearing on asset prices volatility during the sample period as well as during the post-liberalization period alone. We obtain evidence in favour of a nexus between the two phenomena.
\end{abstract}

JEL Classification: E 44 ; G28 ; G21

Key words: asset prices volatility; monetary policy; GARCH

\footnotetext{
*Views expressed here are entirely personal and do not reflect those of the institutions to which the authors belong. The authors gratefully acknowledge the useful comments received from an anonymous referee, Dr. T.K. Chakrabarty, Prof. R. Jha and Prof. M. Jayadev in various stages of the work. An earlier version of the paper was presented at the $40^{\text {th }}$ Conference of the Indian Econometrics Society held at ISEC, Bangalore during February 12-15, 2004. The authors are responsible for remaining errors, if any.
} 


\section{Money-Price Variability and Asset Prices Volatility: Evidence from India}

\section{INTRODUCTION}

Price stability has been one of the most pronounced objectives of monetary policy the world over. In different monetary regimes, this objective has been manifested in various forms. On one hand, there have been explicit inflation targets as in the case of Australia, Canada, New Zealand, United Kingdom etc. On the other hand, a host of macroeconomic variables are used for drawing policy perspectives under multiple indicator approach, as in the case of India, Mexico, South Africa etc. There is an increasing view that price stability and financial stability should be highly complementary and mutually consistent objectives of a central bank (Bernanke and Gertler, 2000). In this regard, there have been a number of studies examining the link between aggregate price stability and asset prices stability. However, most of the existing studies have concentrated on developed economies. In this paper, we review the international evidence on the issue and examine the linkage from an emerging economy perspective. Evidence of stabilizing monetary policy in the recent past has been documented in the Indian context. Monetary policy has been stabilizing in the post-reform period in the sense that the endogenous response of monetary policy to macroeconomic developments has been to minimise fluctuations in economic activity (RBI, 2003). The question that arises here is whether this stability in monetary policy has any ameliorating effect on asset price volatility. Specifically, our objectives in this paper are twofold. First, we review the international evidence on money-price stability and financial stability and second, we empirically examine the linkage between stable monetary policy regime and asset prices stability in the case of India.

Over the last twenty years, significant changes have occurred in the institutional and macroeconomic framework that central banks operate in. In particular, there has been a widespread move towards financial liberalization, both within and across national borders, especially after the 1980s, while inflation rates have become lower and less variable. The 
disinflation process of the 1990s has been a global phenomenon since it is observed both in countries where formal inflation targets are in use, and in non-targeting countries. The decline in inflation has gone hand in hand with a similar decline in interest rates. In many countries, both short term and long-term interest rates are close to, or even below, post-war levels. As Bean (2003) argues, price stability has not been achieved at the expense of the real economy, as unemployment has been decreasing in a number of countries, while growth has also been relatively stable. Despite the good macroeconomic record of the past decade, there has been a growing concern among academics and policymakers that the achievement of price stability may be associated with an increased risk of financial instability.

In a market economy the prices of both financial assets and goods have the role of providing information. They give signals regarding the distribution of resources in the economy. This means that fluctuations in asset prices are useful as long as they reflect changes in expectations regarding the fundamental development of the economy. Optimistic expectations of future growth in the entire economy or in a particular industry can be expressed, for instance, in the form of rising share prices, as there are then expectations of a strong development in profits and a high real return on investment.

If households increase their consumption as a result of exaggerated increases in the value of assets, it could lead to the build-up of large real and financial imbalances. In addition, companies can increase their investments as a result of lower financing costs on a risk capital market with overvalued share prices, but also because a rise in the value of a company's assets increases its credit rating. Therefore, when the bubble bursts and asset prices fall, it could lead to heavily indebted households and companies increasing their savings considerably and to a fall in consumption and investment. Falling asset prices thus risk triggering processes that could eventually lead to a recession. Following the widespread financial deregulation and increased globalisation of capital markets since the early 1980s, industrial economies have witnessed a clear upward trend in asset prices. However, in some cases, such as Japan and Scandinavia during the 
late 1980s and early 1990s, the asset price collapsed after the boom turned out to have serious disruptive effects on the domestic financial system and contributed to prolonged recessions. Furthermore, as the harmful effect of large asset price movements appeared again in emerging markets in the Asian financial crisis, debate about the appropriate response of monetary policy to asset price movements has intensified recently.

Nevertheless, to obtain an appropriate monetary policy response to asset price fluctuations, a better understanding of asset price movements and the linkages between asset prices and inflation is required. Secondly, the existing understanding on the issue of central bank's responding to asset prices is that for monetary policy to respond to asset price movements appropriately, it is crucial to distinguish asset price movements driven by economic fundamentals from asset price bubbles. In light of the above discussion, this paper examines whether price and money variability in India has bearing on asset prices volatility in order to present implications about an appropriate monetary policy regime.

\section{RECEIVED LITERATURE}

Do monetary and price stability contribute to asset price stability? The literature in this regard, although rich and growing, is not yet settled with there being still no clear consensus on how one affects the other. First we review some of the papers dealing with how asset prices are linked to headline prices and monetary policy. Then we take up the issues of whether the central bank should respond to asset price movements and the nexus between monetary or price stability and asset price fluctuations. On the issue of real effects of price variability, Fisher (1933) was one of the early economists to point out that price variability is an important cause of business cycles through its effect on the real cost of debt. Thus one of the ways to view the impact of price variability on the real sector is to look at asset price behaviour (Giammarino, 1999) where studies have shown that aggregate stock returns are negatively related to inflation and to money growth (Bodie, 1976; Fama, 1981; Pearce and Roley, 1983; Chen, Roll and Ross, 1986). On the issue of 
impact of monetary policy on asset price behaviour, Flannery and Protopapadakis (2002) conclude that monetary policy announcements have significant impact on volatility of aggregate equity returns.

Closely linked to the above issues is the question of whether the central bank should respond to asset price movements to achieve price stability. Kent and Lowe (1997) and Cecchetti et al (2000) opine that because of the possible instability of the economy following the financial disturbance caused by asset price fluctuations, the central bank should respond. In general, the bursting of a bubble after a long period of boom causes a serious imbalance in the balance sheets of financial institutions through insolvencies of lending backed by collateral. This aggravates the weakness of financial institutions and induces them to reduce corporate lending. Therefore, the possible credit crunch could contract investment and, finally, trigger recession. Moreover, they argue that another reason for monetary policy to respond to asset price movements is the impact of asset price movements on consumption (through the wealth effect) and investment (through capital gains) via the monetary transmission mechanism due to changes in the value of collateral and asset prices.

There have been a number of studies that have tried to analyse whether monetary policy should respond to asset prices. Bernanke and Gertler (20001), through simulation evidence, prescribe a reactive monetary policy response since they show that a central bank dedicated to price stability should pay no attention to asset prices per se, except insofar as they signal changes to expected inflation. On the other hand, Cecchetti et al (2000), and Kontonikas and Ioannidis (2005) observe that overall macroeconomic volatility can be reduced with a mild reaction of interest rates to asset price misalignments from fundamentals. Econometric evidence by Kontonikas and Montagnoli (2004) for the UK, and Chadha, Sarno and Valente (2003) for UK, US and Japan, suggests that monetary policymakers may use asset prices not only as part of their information set for setting interest rates, but also as elements in their reaction function. 
In fact, according to Issing (2003), price stability and financial stability tend to mutually reinforce each other in the long run. However, according to Kontonikas and Montagnoli (2006), price stability is not a sufficient condition for financial stability. The examples of the US in the 1920s and 1990s and Japan in the late 1980s demonstrate that financial imbalances may build up even in an environment of stable prices (Borio and Lowe, 2002). Exponents of the 'new environment' hypothesis argue that low and stable rates of inflation may even foster asset price bubbles, for instance, due to excessively optimistic expectations about future economic development. Among the exponents of the new environment hypothesis, Crocket (2003) states that: "...if the monetary policy reaction function does not incorporate financial imbalances, the monetary anchor may fail to deliver financial stability".

The consensus among economists and central bankers is that monetary policy should not directly target asset prices, but should respond to the effects of asset price fluctuations to the extent that they signal changes in expected inflation (Bernanke and Gertler, 2000; Batini and Nelson, 2000). However the difficulty of distinguishing asset price movements driven by excess optimism from those led by fundamentals forces the central bank to hesitate about targeting asset prices for monetary policy. Even if the central bank were able to make this distinction, it does not have adequate policy tools to eliminate the bubble alone. The obscurity of the relationship between interest rates and asset prices prevents it from responding to asset price fluctuations efficiently. However, the above cited authors argue that by focusing on reducing the inflationary or deflationary pressures generated by excess real demand, a central bank can respond effectively to the harmful side effects of asset booms and busts without getting into the business of deciding what is or is not a fundamental.

Monetary policy would successfully respond to asset price volatility only if the two phenomenons bear a significant relationship. Errunza and Hogan (1998) conclude that money supply volatility Granger causes equity volatility in Germany and France. Bordo, Dueker and Wheelock (2001) found that aggregate price shocks, which depend on the monetary regime, 
significantly contribute to financial instability. However all of the above studies have focused on developed countries and there is little evidence to show whether price variability has a significant effect on asset price volatility in developing countries. One study by Dasgupta and Sensarma (2003) found that monetary conditions (proxied through reserve money) in India have a significant impact on stock returns. However they examined the levels of the variables, based on a Vector Auto Regression framework, and did not study volatility. ${ }^{1}$

\section{ASSET PRICE VOLATILITY AND MONETARY REGIME: INTERNATIONAL EVIDENCE}

Eichengreen and Tong (2003) analysed the stock markets of 12 developed countries and showed a U-shape relationship of stock market volatility with time, i.e. volatility is initially falling before turning back up in recent decades. In trying to explain these trends, Eichengreen and Tong (2003) found that monetary volatility was positively associated with stock market volatility; an interpretation is that the conduct of monetary policy and the nature of the monetary regime are important for stock market volatility. That monetary policy became increasingly volatile in a number of countries in the 1970s and 1980s thus may be part of the explanation for why stock markets in these countries have been more volatile in recent decades.

But Schwert (1989a), analyzing a long-time series of historical data for the United States, found only weak evidence that stock market volatility is associated with the volatility of the economy. Although he found that both stock returns and output are more volatile in recessions, which can explain why volatility is higher in some periods than others, the additional volatility of activity in such periods appears to be insufficient to explain the additional volatility in asset markets. In sum, most investigators agree that there has been a secular decline in macroeconomic volatility in the now-advanced economies. But while this decline in output volatility has been broadly linear, the same has not been true of stock market volatility. Thus, it is hard to see how the former can explain the latter. At a minimum, other factors must also be at work. Worrell and 
Leon (2001) observed that for Brazil, Korea, Mexico and Norway, price volatility had no connection with financial instability while for Canada, Jamaica, Bangladesh, Jordan and New Zealand, high volatility in price indicators preceded a period of financial difficulty.

Lack of evidence of a significant impact of economic volatility on stock market volatility, such as in Schwert (1989a), have led researchers in two directions. Schwert (1989a) himself posited that there might be increasing uncertainty about policy and performance in certain periods (he emphasised periods of slow growth and recession). Thus, the rise in stock market volatility in such periods could reflect not just the actual increase in the volatility of the economy but the even greater increase in expected volatility (and dispersion of expectations). Volatility could, thus, be driven by a small and changing probability of extreme events (the collapse of markets in the Great Depression, for example), events that may not in fact be observed in the sample period. Schwert (1989b) also suggested that bank failures and related forms of financial distress are more prevalent in such periods and that these events are associated with stock market volatility, both because they disrupt the operation of the financial system (including the stock market) and because they raise the probability of sharp policy changes in response.

But while Schwert's mechanism can amplify the relationship between output volatility and stock market volatility, it cannot obviously explain the non-linear pattern in volatility levels widely observed. Subsequently, some authors challenged Schwert's conclusion that changes in stock market volatility cannot be adequately explained by observed changes in macroeconomic policies and conditions. In effect, they responded by introducing additional macroeconomic variables.

Binder and Merges (2001) regressed the volatility of the US S\&P Composite Index on measures of monetary uncertainty, the risk premium, and the risk-free rate. All of these variables entered with significant coefficients. In effect, they reversed Schwert's conclusion by augmenting his list of macroeconomic variables to include additional monetary and financial factors. Similarly, Errunza and Hogan (1998) show that the variability of European stock returns is 
associated not just with the fluctuation of output but also with that of money supply. They argue that the two factors - macroeconomic volatility and financial volatility - go a long way together toward explaining observed stock market volatility. In this paper we investigate the roles of money variability and price variability in explaining stock market volatility in India.

\section{DATA AND STYLIZED FACTS FOR THE INDIAN ECONOMY}

For the present paper, asset prices have been proxied by data on equity returns (RET) computed based on the index of The Stock Exchange, Mumbai (popularly known as the Bombay Stock Exchange or BSE), which is the SENSEX (Sensitive Index). SENSEX is a market capitalisation-weighted index of 30 stocks representing a sample of large, well established and financially sound companies. The index is widely used to measure the performance of the Indian stock markets. We compute inflation (INF) based on data on wholesale price index (WPI). We also construct money supply growth based on data on broad money (M3). We have taken monthly data during period 1980:04 to 2003:03. All data are taken from the Handbook of Statistics on the Indian Economy, 2002-03.

The pursuit of price stability was central to the process of financial sector reforms initiated in the 1990s. Although inflation was not targeted in the 1990s, monetary policy was formulated with the stated objective of curbing inflationary expectations. The projected inflation rate was gradually scaled down to 4-5 per cent in the last few years from around to 7-9 per cent indicated in the early part of the 1990s (RBI, 2003).

The Indian inflation record over the period can be considered satisfactory as compared with many developing economies which in turn can be attributed to appropriate monetary management, coupled with measures to contain adverse supply shocks. As a consequence, trends in WPI inflation rate over the past five decades which averaged to 6.6 per cent per annum witnessed steady decline decade-wise from 9.0 per cent in the 1970 s to 8.0 per cent in 1980 s with 
a corresponding decline in volatility in inflation rate, as measured by coefficient of variation to 0.4-1.0 per cent in the subsequent decades (RBI, 2003).

Evidence of stabilizing monetary policy in the recent past has also been documented in the literature. In India, monetary policy has been stabilizing in the post-reform period in the sense that the endogenous response of monetary policy to macroeconomic developments has been to minimise fluctuations in economic activity (RBI, 2003). ${ }^{2}$ This result is also consistent with the evidence emerging from studies in the context of the US (Boivin and Giannoni, 2002).

The scenario in the 1980 s and 1990 s is presented in Table 1 . As can be seen from the table, variability (measured by coefficient of variation) in M3 growth, WPI as well as the stock index (BSE Sensex) seem to be have gone up together during the late eighties to mid-nineties, i.e. around the period of economic reforms, and subsequently declined in the latter half of the 1990s.

Table 1: Variability in M3, WPI and BSE Sensex since the 1980s

\begin{tabular}{|l|r|r|r|}
\hline Period & M3 Growth & WPI & BSE Sensex \\
\hline $1981-1985$ & 11 & 7 & 12 \\
\hline $1986-1990$ & 7 & 13 & 35 \\
\hline $1991-1995$ & 12 & 15 & 28 \\
\hline $1996-2002$ & 9 & 9 & 17 \\
\hline
\end{tabular}

Note: The numbers represent coefficients of variation for each variable expressed in percentage.

Charts 1 and 2 show the movement in stock returns, inflation and money supply growth during the sample period. As expected, volatility for all the three variables appears to have increased during the period of the economic reforms in 1991 and the stock market scam in 1992. 
Chart 1: Stock Returns during the Sample Period (1980-2003)

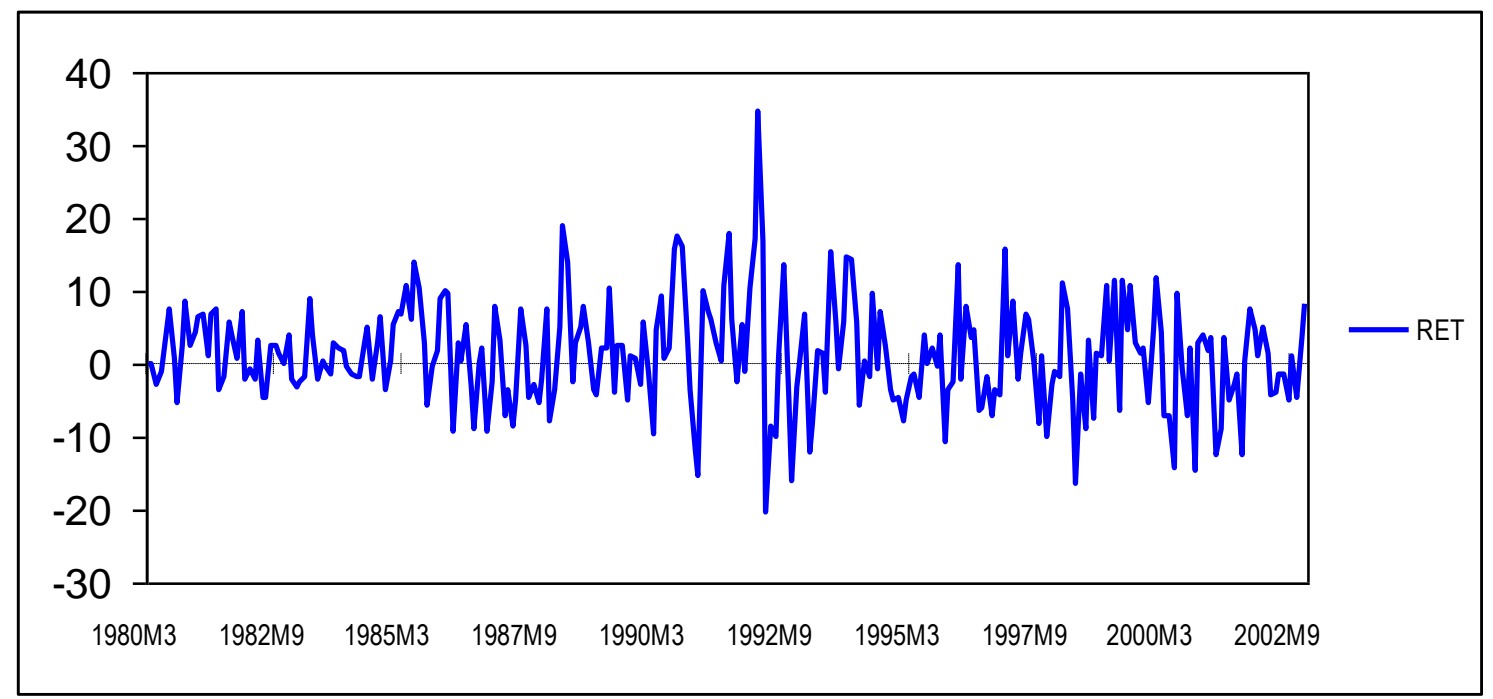

Chart 2: Money Growth and Inflation during the Sample Period (1980-2003)

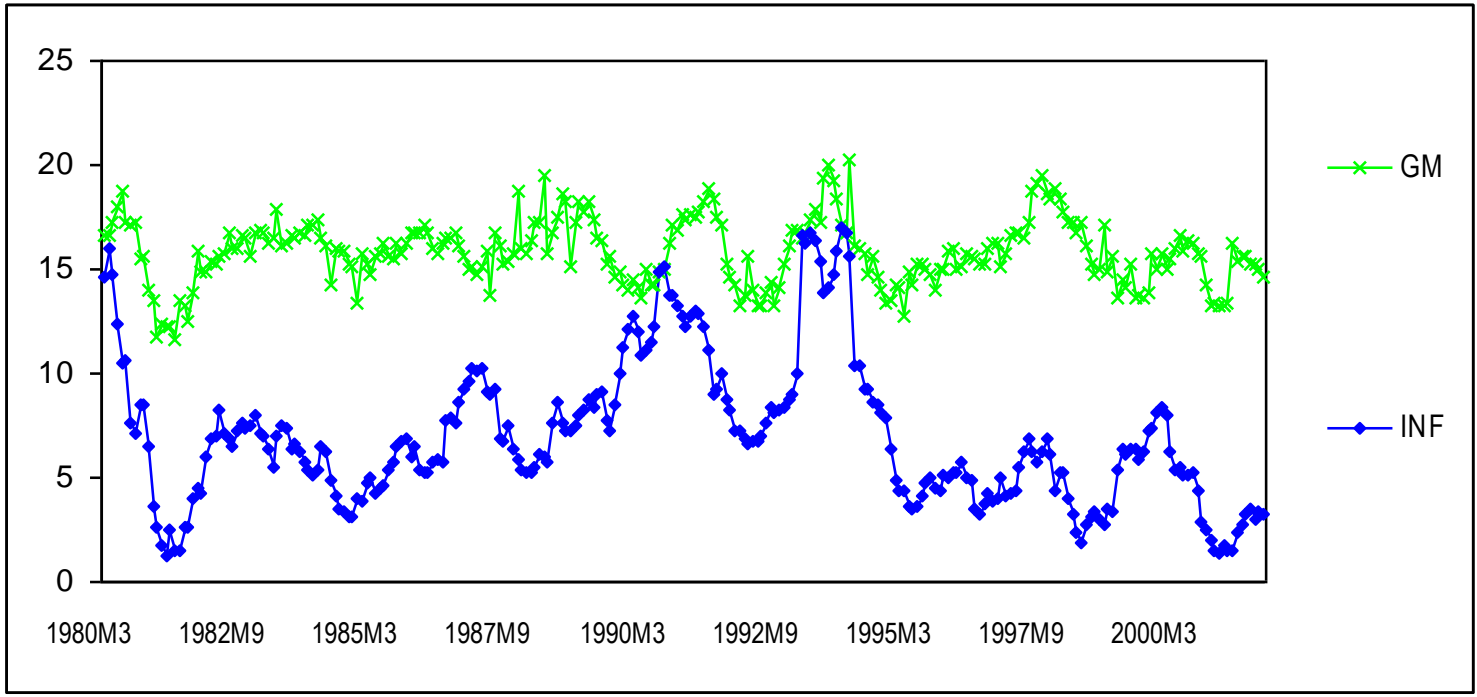

Note: GM denotes growth in M3 (year-on-year) and INF denotes Inflation (year-on-year)

\section{ECONOMETRIC METHODOLOGY}

Following Eichengreen and Tong (2003), there are several common ways of estimating volatility. One approach is to compute the standard deviation of returns over successive periods of time - for example, to take end-of-month data for the 12 months of the year and calculate volatility as the standard deviation of those 12-monthly observations, and then to roll the window 
forward in time (drop month 1 and add month 13). This boils down to computing (equally weighted) moving average of squared mean deviations of returns. An application of this method is Officer (1973). A problem with Officer's approach is that the use of overlapping observations will create a correlation between standard deviations at different points in time. An alternative is to use non-overlapping observations: to compute the standard deviation using, say, months 1 through 12,13 through 24 , and so forth. The problem here is that the periodization is arbitrary and the result is relatively few data points. In practice, however, similar results are obtained using the two approaches. An alternative is to specify a parametric model of asset returns and to use it to derive estimates of volatility.

Based on the observation of serially correlated volatility, Engle (1982) introduced the Auto Regressive Conditionally Heteroskedastic (ARCH) model as a basis for deriving such estimates. Bollerslev (1986) further generalized the ARCH model and suggested the Generalized Auto Regressive Conditionally Heteroskedastic (GARCH) model which has become the most popular approach to study volatility. The GARCH model starts by specifying an equation for the conditional mean of stock returns. Because the current stock return may depend on past stock returns, the equation for the mean is specified to allow for inter-temporal dependence:

$R_{t}=A_{0}+A_{1} R_{t-1}+A_{1} R_{t-2}+\ldots+A_{S} R_{t-S}+u_{t}$

where $R_{t}$ is the stock return at time $t, \mathrm{~A}_{0}$ is a constant term, and $u_{t}$ is the disturbance. The disturbance is modelled as: $\mathrm{u}_{\mathrm{t}}=\sqrt{h_{t} v_{t}}$, where $v_{t}$ has the i.i.d. normal distribution with zero mean and unit variance, and $h_{t}$ evolves according to:

$\mathrm{h}_{\mathrm{t}}=\mathrm{k}+\beta_{1} \mathrm{~h}_{\mathrm{t}-1}+\ldots+\beta_{p} \mathrm{~h}_{\mathrm{t}-\mathrm{p}}+\alpha_{1} u_{t-1}^{2}+\ldots+\alpha_{q} u_{t-q}^{2}$

This is the GARCH $(p, q)$ model, where the equations for the conditional mean and variance can be jointly estimated using maximum likelihood. In case of the present study, AR(1)$\operatorname{GARCH}(1,1)$ appears to be the appropriate specification based on Akaike Information Criterion 
(AIC) and Schwarz Bayesian Criterion (SBC). ${ }^{3}$ We specify the AR(1)-GARCH $(1,1)$ model as follows:

$\mathrm{R}_{\mathrm{t}}=\mathrm{A}_{0}+\mathrm{A}_{1} \mathrm{R}_{\mathrm{t}-1}+\mathrm{u}_{\mathrm{t}}$

$\mathrm{h}_{\mathrm{t}}=\mathrm{k}+\beta_{1} \mathrm{~h}_{\mathrm{t}-1}+\alpha_{1} u_{t-1}^{2}$

In the $\operatorname{GARCH}(1,1)$ model, $\beta_{1}$ measures the extent to which a volatility shock today translates into volatility tomorrow, while $\alpha_{1}$ measures the rate at which volatility dissipates over time. If $\alpha_{1}+\beta_{1}<1$, then $u_{t}^{2}$ will be covariance stationary, and the unconditional mean of $u_{t}^{2}$ will be $\mathrm{E}\left(\mathrm{h}_{\mathrm{t}}\right)=\mathrm{k} /(1-\alpha-\beta)$.

\section{RESULTS AND DISCUSSION}

The purpose of our empirical exercise is two-fold. First, we study the impact of headline prices variability on asset prices volatility. This enables us to analyse whether achievement of stability in headline prices can have implications for stability in asset prices. Second, we study the impact of variability in broad money growth on asset prices volatility. This is important for understanding whether a stable monetary regime is associated with stable asset prices. The first step in either exercise is to arrive at a measure of asset price volatility, using a GARCH model.

At the outset we test for whether stock returns (RET, henceforth) is a stationary series. Since we will examine the full period of 1980 to 2003 and the post-liberalization period of 1992 to 2003 separately in our empirical analysis, we conduct the stationarity tests for both these periods. A stationary series is one which is mean reverting or does not contain a unit root. It is represented as a series which is integrated of order zero, or $\mathrm{I}(0)$. To test for stationarity, we first conduct the Augmented Dickey Fuller (ADF) test based on the auxiliary regression of first difference of RET on lagged RET and lagged first differences of RET. We conduct the test, first without a linear trend and then with a linear trend, in a sequential manner as described in Lim and McAleer (2001). In order to determine the number of lagged first differences to be included, an 
initial lag length of 12 is selected, and the twelfth lag is tested for significance using the standard asymptotic t-ratio. If the twelfth lag is insignificant, the lag length is reduced successively until a significant lag length is obtained. In our case, no lagged first difference eventually gets selected, thereby reducing the ADF test to the Dickey-Fuller (DF) test. Table 1 presents the results of the ADF tests which reveal that the absolute values of the ADF statistics are higher than that of the critical values from the non-standard Dickey-Fuller distribution at $1 \%$ level of significance. Thus the null hypothesis of non-stationarity is rejected implying that the series is indeed stationary. To support our ADF test results, we also conduct the Phillip-Perron (PP) test whose null hypothesis is non-stationarity and Kwiatkowski-Phillips-Schmidt-Shin (KPSS) test whose null hypothesis is stationarity. For both with and without linear trend, the tests reveal that the RET series is stationary for the full period as well as for the post-liberalization period.

Table 2: Results of Unit Root tests for RET

\begin{tabular}{|l|r|r|r|r|r|r|r|r|}
\hline $\begin{array}{l}\text { Unit } \\
\text { Root } \\
\text { Tests }\end{array}$ & $\begin{array}{r}\text { With intercept, } \\
\text { without linear } \\
\text { trend }(1980 \text { to } \\
2003)\end{array}$ & \multicolumn{2}{|r|}{$\begin{array}{r}\text { With intercept, } \\
\text { with linear trend } \\
(1980 \text { to 2003) }\end{array}$} & $\begin{array}{r}\text { With intercept, } \\
\text { without linear trend } \\
(1992 \text { to 2003) }\end{array}$ & \multicolumn{2}{|r|}{$\begin{array}{r}\text { With intercept, } \\
\text { with linear trend } \\
(1992 \text { to 2003) }\end{array}$} \\
\cline { 2 - 9 } & $\begin{array}{r}\text { Test } \\
\text { Statistic }\end{array}$ & $\begin{array}{r}\text { Critical } \\
\text { Value }\end{array}$ & $\begin{array}{r}\text { Test } \\
\text { Statistic }\end{array}$ & $\begin{array}{r}\text { Critical } \\
\text { Value }\end{array}$ & $\begin{array}{r}\text { Test } \\
\text { Statistic }\end{array}$ & $\begin{array}{r}\text { Critical } \\
\text { Value }\end{array}$ & $\begin{array}{r}\text { Test } \\
\text { Statistic }\end{array}$ & $\begin{array}{r}\text { Critical } \\
\text { Value }\end{array}$ \\
\hline $\begin{array}{l}\text { ADF } \\
\text { Test } \\
(\text { lag=0) }\end{array}$ & -12.262 & -3.454 & -12.349 & -3.992 & -10.487 & -4.029 & -10.423 & -3.481 \\
\hline $\begin{array}{l}\text { PP } \\
\text { Test }\end{array}$ & -12.014 & -3.454 & -12.113 & -3.992 & -10.512 & -3.481 & -10.443 & -4.029 \\
\hline $\begin{array}{l}\text { KPSS } \\
\text { Test }\end{array}$ & 0.280 & 0.739 & 0.067 & 0.216 & 0.085 & 0.739 & 0.031 & 0.216 \\
\hline
\end{tabular}

Note: All critical values are reported at $1 \%$ level of significance.

Next, we need to test whether RET follows a GARCH process. For this purpose we conduct Engle's LM test on the full period as well as the post-liberalization period. Accordingly, we regress RET on its lagged value and test for $\mathrm{ARCH}$ effects in the estimated residuals. The result of this test rejects the null hypothesis of no ARCH effects for both periods. ${ }^{4}$ This suggests 
that RET should be modeled as a GARCH process. Accordingly, we estimate the appropriate GARCH models for the RET series and the estimated models are provided in Table 3.

Table 3(a): AR (1)-GARCH (1,1) assuming a Normal Distribution - Parameters of the Mean Equation

\begin{tabular}{|c|r|r|}
\hline Regressor & 1980 to 2003 & 1992 to 2003 \\
\hline C & 0.812 & -0.026 \\
\hline RET(-1) & $0.252^{*}$ & $0.136^{*}$ \\
\hline Adjusted R-Square & 0.071 & 0.022 \\
\hline
\end{tabular}

Table 3(b): Parameters of the Conditional Heteroscedastic Model - Explaining the Conditional Variance of the Error Term

\begin{tabular}{|l|r|r|}
\hline Regressor & 1980 to 2003 & 1992 to 2003 \\
\hline Constant & 1.055 & $3.868^{*}$ \\
\hline E-Square(- 1) & $0.122^{*}$ & 0.049 \\
\hline H-Square(- 1) & $0.861^{*}$ & $0.859^{*}$ \\
\hline
\end{tabular}

Note: H-Square stands for the conditional variance of the error term, E-Square stands for the square of the error term,

* indicates significance at $1 \%$.

Statistically significant but small ARCH coefficients indicate the weak reaction of conditional variance to past shocks, while the dimensionally stronger and statistically significant GARCH coefficients signify strong persistence in conditional variance.

We saved the conditional variance obtained from the GARCH model which gives us the volatility of stock returns (VOLRET). We first explore the interlinkage between price variability and stock market volatility. In order to capture price variability, we have used inflation (INF) and deviation of WPI (DWPI). To construct the latter, we computed means over rolling windows of 12 months each, and took the absolute deviation of monthly WPI from its corresponding window's mean. Then we regressed VOLRET on INF and DWPI to ascertain whether price variability has any effect on stock market volatility. We included a dummy variable for economic reforms in June 1991 to capture the impact of reforms which are expected to have made the stock markets more active and vibrant. ${ }^{5}$

Our findings are as follows. First, inflation was found to have a positive and significant impact on VOLRET (see Column 2, Table 4). This suggests that periods of low stock market 
volatility are associated with low inflation. Moreover, the reforms dummy was found to be positive and significant, thus indicating that stock market volatility went up after reforms. Next, DWPI was found to have a positive and significant impact on VOLRET (see Column 3, Table 4). In other words, stock market volatility is positively associated with price variability. Once again the reforms dummy was positive and significant.

Next, we explore the interlinkage between money variability and stock market volatility. Similar to the case of WPI, we constructed DM3 to capture money variability based on broad money growth. Then, we regressed VOLRET on DM3 and found that the coefficient of DM3 is positive and significant (see Column 4, Table 4). This suggests that periods of low stock market volatility were also the ones where money growth was stable. The reforms dummy was positive and significant, reiterating the fact that stock market volatility increased subsequent to reforms.

We estimated two more models to look at the joint impact of price variability and money variability on stock market volatility. We included both INF and DM3 along with the reforms dummy in the above specification to examine whether price and money variability together affect stock market volatility. The results given in Column 5, Table 4 indicate that while INF appears to be significantly associated with VOLRET, the coefficient of DM3 turns out to be statistically insignificant. This may be happening because of the relatively higher variability in the INF series as compared with the DM3 series. Next, when we replace INF with DWPI, we obtain similar results (Column 6, Table 4).

Table 4: Regression Results of GARCH-VOLRET on Money-Price Variability (1980-2003)

\begin{tabular}{|l|r|r|r|r|r|}
\hline Regressor & & & & & \\
\hline Constant & $4.976(.000)$ & $5.454(.000)$ & $5.561(.000)$ & $4.887(.000)$ & $5.325(.000)$ \\
\hline DUMMY & $1.769(.000)$ & $1.468(.000)$ & $1.758(.000)$ & $1.709(.000)$ & $1.414(.000)$ \\
\hline INF & $0.119(.000)$ & & & $0.114(.000)$ & \\
\hline DWPI & & $0.071(.004)$ & & & $0.066(.007)$ \\
\hline DM3 & & & $0.217(0.064)$ & $0.147(.201)$ & $0.181(.121)$ \\
\hline $\begin{array}{l}\text { Adjusted R- } \\
\text { Square }\end{array}$ & 0.296 & 0.264 & 0.251 & 0.298 & 0.268 \\
\hline F-Stat & $58.469(.000)$ & $50.061(.000)$ & $46.793(.000)$ & $39.619(.000)$ & $34.355(.000)$ \\
\hline
\end{tabular}

Note: Numbers in parentheses are p-values. 
It may be argued that GARCH is only one way of estimating stock market volatility. For the sake of robustness, we try out alternative ways of estimating stock market volatility and repeat the above estimation exercises with other volatility measures. We follow Alexander (2001) in exploring alternative measures of stock market volatility. There are two popular notions of stock market volatility, viz. implied volatility and statistical volatility. Implied volatility is the volatility implied by the market price of a derivative based on a theoretical pricing model such as the Black-Scholes option pricing model. However this measure rarely corresponds to the realised volatility (the actual volatility of the stochastic process governing the price movements) since implied volatility includes future expectations of price movements of price movements, which are not reflected in historical prices. On the other hand, statistical volatility uses historical price data and employs an appropriate statistical model to give unconditional or conditional volatility. Unconditional volatility estimates can be obtained by using equally weighted Moving Average (MA) methods or Exponentially Weighted Moving Average (EWMA) method whereas conditional or time-varying volatility estimates can be obtained by using a GARCH model. Since we have already made use of the latter, we now compute MA and EWMA measures of VOLRET.

We compute MA based VOLRET (MA-VOLRET) by applying moving average to squared mean deviations of returns, over a rolling window of 12 months. On the other hand, EWMA based VOLRET (EWMA-VOLRET) is a weighted moving average where the weight is $\lambda^{\mathrm{i}-1}$ for the $(\mathrm{t}-\mathrm{i})^{\text {th }}$ month's squared returns. While volatility in most markets produces values of $\lambda$ between 0.75 and 0.98 , we use the value 0.97 which is recommended by RiskMetrics (Mina and Xiao, 2001) in the case of monthly data. Our results for the regression of these two alternative stock market volatility measures on price and money variability are reported in Table 5 (for MA) and Table 6 (for EWMA). It can be deciphered from the tables that our earlier results are qualitatively unchanged. In fact for the EWMA measure of stock market volatility, money and price variability turn out be jointly affecting VOLRET. Thus we conclude that during the period 
1980 to 2003 , we are able to provide evidence that asset price volatility is significantly affected by money-price variability.

Table 5: Regression Results of MA-VOLRET on Money-Price Variability (1980-2003)

\begin{tabular}{|l|r|r|r|r|r|}
\hline Regressor & & & & & \\
\hline Constant & $7.1077(.175)$ & $27.268(.000)$ & $25.770(.000)$ & $5.091(.427)$ & $21.774(.000)$ \\
\hline DUMMY & $30.815(.000)$ & $25.305(.000)$ & $28.359(.000)$ & $28.204(.000)$ & $23.392(.000)$ \\
\hline INF & $3.515(.000)$ & & & $3.126(.000)$ & \\
\hline DWPI & & $1.116(.083)$ & & & $1.001(.118)$ \\
\hline DM3 & & & $7.221(.018)$ & $6.168(.036)$ & $6.843(.025)$ \\
\hline $\begin{array}{l}\text { Adjusted R- } \\
\text { Square }\end{array}$ & 0.223 & 0.127 & 0.136 & 0.194 & 0.141 \\
\hline F-Stat & $40.712(.000)$ & $20.145(.000)$ & $21.671(.000)$ & $22.069(.000)$ & $15.347(.000)$ \\
\hline
\end{tabular}

Note: Numbers in parentheses are p-values

Table 6: Regression Results of EWMA-VOLRET on Money-Price Variability (1980-2003)

\begin{tabular}{|l|r|r|r|r|r|}
\hline Regressor & & & & & \\
\hline Constant & $5.786(.090)$ & $20.244(.000)$ & $22.311(.000)$ & $1.878(.592)$ & $14.904(.000)$ \\
\hline DUMMY & $36.414(.000)$ & $26.668(.000)$ & $35.237(.000)$ & $33.762(.000)$ & $24.425(.000)$ \\
\hline INF & $3.680(.000)$ & & & $3.469(.000)$ & \\
\hline DWPI & & $2.266(.000)$ & & & $2.083(.000)$ \\
\hline DM3 & & & $8.635(.000)$ & $6.490(.000)$ & $7.494(.000)$ \\
\hline $\begin{array}{l}\text { Adjusted R- } \\
\text { Square }\end{array}$ & 0.474 & 0.389 & 0.364 & 0.497 & 0.420 \\
\hline F-Stat & $123.914(.000)$ & $87.784(.000)$ & $79.150(.000)$ & $90.798(.000)$ & $66.820(.000)$ \\
\hline
\end{tabular}

Note: Numbers in parentheses are p-values

So far in our estimations we have used a dummy variable to proxy the economic reforms

of 1991. However it may be argued that the stock market became mature and vibrant only after

SEBI was set up in February 1992 and subsequently foreign institutional investment (FII) in

Indian stock markets was liberalized in September 1992. Hence it may be useful to look at the above relationships subsequent to these measures. Therefore, we select the sub-period 1992:03 to 2003:03 to examine the interaction between asset price volatility and money-price variability. The results of the analysis for this post-liberalization period are provided in Tables 7 to 9 . It can be observed that our earlier results carry through even to the post-liberalization period (even though the model fit is often poorer as indicated by some low values of adjusted R-square and insignificant F-statistics). In other words, there is a positive and significant association between stock market volatility and money-price variability in the post-liberalization period. In fact if we 
consider the period 1992:09 to 2003:03, i.e. the period after liberalization of FII inflows, the results remain qualitatively unchanged. ${ }^{6}$

Table 7: Regression Results of GARCH-VOLRET on Money-Price Variability (1992-2003)

\begin{tabular}{|l|r|r|r|r|r|}
\hline Regressor & & & & & \\
\hline Constant & $6.539(.000)$ & $7.341(.000)$ & $7.059(.000)$ & $6.379(.000)$ & $6.947(.000)$ \\
\hline INF & $0.154(.000)$ & & & $0.141(.002)$ & \\
\hline DWPI & & $0.025(.000)$ & & & $0.014(.680)$ \\
\hline DM3 & & & $0.411(.049)$ & $0.203(.338)$ & $0.397(.061)$ \\
\hline $\begin{array}{l}\text { Adjusted R- } \\
\text { Square }\end{array}$ & 0.085 & -0.004 & 0.022 & 0.085 & 0.016 \\
\hline F-Stat & $13.336(.000)$ & $0.519(.472)$ & $3.944(.049)$ & $7.076(.001)$ & $2.045(.134)$ \\
\hline
\end{tabular}

Note: Numbers in parentheses are p-values

Table 8: Regression Results of MA-VOLRET on Money-Price Variability (1992-2003)

\begin{tabular}{|l|r|r|r|r|r|}
\hline Regressor & & & & & \\
\hline Constant & $38.861(.000)$ & $62.301(.000)$ & $45.155(.000)$ & $31.4325(.002)$ & $48.400(.000)$ \\
\hline INF & $3.462(.004)$ & & & $2.8397(.022)$ & \\
\hline DWPI & & $-.0414(.964)$ & & & $-40810(.659)$ \\
\hline DM3 & & & $13.576(.016)$ & $9.373(.108)$ & $13.982(.000)$ \\
\hline $\begin{array}{l}\text { Adjusted R- } \\
\text { Square }\end{array}$ & .0557 & -.008 & .0361 & 0.067 & 0.030 \\
\hline F-Stat & $8.734(.004)$ & $0.002(.964)$ & $5.904(.016)$ & $5.733(.004)$ & $3.032(.052)$ \\
\hline
\end{tabular}

Note: Numbers in parentheses are p-values

Table 9: Regression Results of EWMA-VOLRET on Money-Price Variability (1992-2003)

\begin{tabular}{|l|r|r|r|r|r|}
\hline Regressor & & & & & \\
\hline Constant & $34.012(.000)$ & $52.820(.000)$ & $50.260(.000)$ & $28.141(.000)$ & $39.997(.000)$ \\
\hline INF & $5.069(.000)$ & & & $4.577(.000)$ & \\
\hline DWPI & & $1.629(.009)$ & & & $1.291(.033)$ \\
\hline DM3 & & & $14.181(.000)$ & $7.406(.031)$ & $12.897(.001)$ \\
\hline $\begin{array}{l}\text { Adjusted R- } \\
\text { Square }\end{array}$ & 0.285 & 0.044 & 0.095 & 0.305 & 0.120 \\
\hline F-Stat & $53.328(.000)$ & $7.004(.009)$ & $14.795(.000)$ & $29.801(.000)$ & $9.932(.000)$ \\
\hline
\end{tabular}

Note: Numbers in parentheses are p-values

Therefore we are able to obtain evidence to suggest that during the period 1980 to 2003 as well as during the post-liberalization period alone, stock market volatility has a positive and significant association with both price variability and money variability. In other words, a monetary policy regime, which addresses price stability successfully, might have an ameliorating effect on asset price volatility as well. 


\section{CONCLUDING REMARKS}

This paper studies the impact of variability in aggregate prices and money supply growth on asset price volatility. The literature suggests that countries associated with price stability are usually the ones to have experienced financial stability. It has also been argued that countries which have pursued stable monetary policy regimes have achieved stability in asset prices. Along these lines, we explore the extent to which there exists a link between volatility of asset prices on one hand, and variability of money supply and aggregate prices on the other hand, in India.

Using monthly data from April 1980 through March 2003, we estimate stock market volatility employing GARCH, MA and EWMA models and then investigate whether asset price volatility is affected by price and money supply variability. We found that variability in both money and prices positively and significantly affect stock market volatility. This finding may have implications on the applicability of inflation targeting as a monetary policy framework. If variability in inflation is considerably reduced, then it may have a mitigating effect on asset price volatility and thereby help in achieving financial stability.

The research initiated in the present paper in no way claims to be complete. It is important to examine issues such as the role of credit variability or core inflation in affecting stock returns volatility, instead of money and headline price variability. Correlations between money-price variability and financial instability may be studied by using specific indicators of monetary regime in the variance equation of the GARCH model, subject to data availability. Moreover the issue of nexus between the variables over different time-horizons needs to be addressed given the long and variable lags of monetary policy transmission. These are the issues we wish to take up in our future research. 


\section{END NOTES}

1. Ray and Chatterjee (2001), through a VAR analysis, studied the impact of stock returns on commodity price inflation.

2. The proportion of variance in output and prices arising out of monetary policy shocks has declined during 1994:04-2002:12 compared to the period 1981:04-1990:06.

3. The AIC and SBC values for $\operatorname{AR}(s)-G A R C H(p, q)$ were computed for different values of s, p and q. The minimum AIC and SBC values of -898.923 and -906.149 for the full period, and -443.1797 and -448.9453 for the post-liberalization period were obtained for the AR(1)-GARCH(1,1) specification.

4. Lagrange Multiplier Statistic of the test for $\mathrm{ARCH}$ effects has the value Chi-Square statistic $($ d.f. $=12)=31.4228[.002]$ and F Statistic has the value F $(12,260)=2.8066$ [.001], both of which reject the null hypothesis of no ARCH effects at $1 \%$ level of significance. For the post-liberalization period, Lagrange Multiplier Statistic of the test for ARCH effects has the value Chi-Square statistic (d.f.=12) $=19.2470$ [.083] and F Statistic has the value F $(12,118)=1.6786$ [.080], both of which reject the null hypothesis of no ARCH effects at $10 \%$ level of significance. Neither of the price and money variability indicators exhibited any ARCH effects in either period

5. We also tried a dummy for the stock market scam of 1992, but the results remained qualitatively unchanged.

6. The results for this period are not reported to save space, but are available on request. 


\section{REFERENCES}

1. Alexander, C. (2001) Market Models: A Guide to Financial Data Analysis, John Wiley \& Sons, Ltd., New York

2. Batini, Nicoletta and Edward Nelson (2000): 'When the Bubble Bursts: Monetary Policy Rules and Foreign Exchange Market Behaviour', Bank of England Working Paper.

3. Bean, Charles (2003): 'Asset Prices, Financial Imbalances and Monetary Policy: Are Inflation Targets Enough?', in Richards, Anthony and Tim Robinson (eds.), Asset Prices and Monetary Policy, Reserve Bank of Australia.

4. Bernanke, Ben and Mark Gertler (2000): 'Monetary Policy and Asset Price Volatility', NBER Working Paper, No. 7559.

5. Bernanke, Ben and Mark Gertler (2001): 'Should Central Banks Respond to Movements in Asset Prices?', American Economic Review Papers and Proceedings, 91(2), 253-257.

6. Binder, J. J. and Merges, M. J. (2001): 'Stock Market Volatility and Economic Factors', Review of Quantitative Finance and Accounting, 17(1), 5-26.

7. Bodie, Zvi (1976): 'Common Stocks as Hedge against Inflation', Journal of Finance, $31(2), 459-70$.

8. Boivin, J. and M. Giannoni (2002): 'Assessing Changes in the Monetary Transmission Mechanism: A VAR Approach', Federal Reserve Bank of New York Economic Policy Review, May, 97-111.

9. Bollerslev, T.P. (1986):'Generalized Autoregressive Conditional Heteroscedasticity', Journal of Econometrics, 31, 307-327.

10. Bordo, Michael D., Michael J. Dueker and David C. Wheelock (2001): 'Aggregate Price Shocks and Financial Stability: The United Kingdom 1796-1999’, Federal Reserve Bank of St. Louis Working Paper No. 2001-018A.

11. Borio, C.E.V. and P. Lowe (2002): 'Asset Prices, Financial and Monetary Stability: Exploring the Nexus', BIS Working Paper No. 114. 
12. Cecchetti, S., H. Genberg, J. Lipsky and S. F. Wadhwani (2000): 'Asset Prices and Central Bank Policy', Geneva Reports on the World Economy 2, CEPR and ICMB.

13. Chadha, J., L. Sarno and G. Valente (2003): 'Monetary Policy Rules, Asset Prices and Exchange Rates’ CEPR Discussion Paper No. 4114.

14. Chen, Nai Fu, Richard Roll, and Steve Ross (1986): 'Economic Forces and the Stock Market', Journal of Business, 59(3), 383-403.

15. Crocket, A. (2003): 'International Standard Setting in Financial Supervision', Lecture delivered at the Cass Business School, City University, London on $5^{\text {th }}$ February.

16. Dasgupta, Padmini and Sensarma, Rudra (2003): 'Monetary Policy and Predictability of Stock Returns', Paper presented at the $5^{\text {th }}$ Annual Conference on Money and Finance in the Indian Economy, IGIDR, Mumbai, January $31^{\text {st }}$-February $1^{\text {st }}$.

17. Eichengreen, Barry and Hui Tong (2003): 'Stock Market Volatility and Monetary Policy: What the Historical Record Shows', University of California Working Paper, Berkeley.

18. Engle, R.F. (1982): ‘Autoregressive Conditional Heteroscedasticity with Estimates of the Variance of U.K. Inflation', Econometrica, 50, 987-1008.

19. Errunza, Vihang and Ked Hogan (1998): 'Macroeconomic Determinants of European Stock Market Volatility’, European Financial Management, 4(3), 361-377.

20. Fama, E. F. (1981): 'Stock Returns, Real Activity, Inflation, and Money', American Economic Review, 71(4), 545-65.

21. Fisher, Irving (1933): 'The Debt-Deflation Theory of Great Depressions', Econometrica, $1(4), 337-357$.

22. Flannery, Mark J. and Aris A. Protopapadakis (2002): 'Macroeconomic Factors Do Influence Aggregate Stock Returns', Review of Financial Studies, 15, 751-782.

23. Giammarino, R. (1999):'Central Bank Policy, Inflation and Stock Prices', Bank of Canada Working Paper. 
24. Issing, O. (2003): 'Monetary and Financial Stability: Is there a trade-off?', Paper presented at the Conference on 'Monetary Stability, Financial Stability and the Business Cycle', Bank for International Settlements, Basel, March $28^{\text {th }}-29^{\text {th }}$.

25. Kent C and P Lowe (1997): 'Asset-Price Bubbles and Monetary Policy’, Reserve Bank of Australia Research Discussion Paper No. 9709.

26. Kontonikas, A. and C. Ioannidis (2005): 'Should Monetary Policy Respond to Asset Price Misalignments?', Economic Modelling, 22, 1105-1121.

27. Kontonikas, A. and A. Montagnoli (2004): 'Has Monetary Policy Reacted to Asset Price Movements: Evidence from the UK', Ekonomia, 7(1), 18-33.

28. Kontonikas, A. and A. Montagnoli (2006): 'Optimal Monetary Policy and Asset Price Misalignments', Scottish Journal of Political Economy, forthcoming.

29. Lim, C. and McAleer, M. (2001): 'Cointegration analysis of quarterly tourism demand by Hong Kong and Singapore for Australia', 33 (12), 1599-1619.

30. Mina, Jorge and Xiao, Jerry (2001): 'Return to Riskmetrics: Evolution of a Standard', Riskmetrics Group, Inc., New York.

31. Officer, R. (1973): 'The Variability of the Market Factor of the New York Stock Exchange', Journal of Business, 46, 433-453.

32. Pearce, D. K. and V. V. Roley (1983): 'The Reaction of Stock Prices to Unanticipated Changes in Money: A Note', Journal of Finance, 38(4), 1323-1333.

33. Ray, Partha and Somnath Chatterjee (2001): 'The Role of Asset Prices in Indian Inflation in Recent Years: Some Conjectures', BIS Working Paper No. 8.

34. Reserve Bank of India (2003): 'Report on Currency and Finance 2001-02'.

35. Reserve Bank of India (2003): 'Handbook of Statistics on the Indian Economy, 2002-03'.

36. Schwert, G. William (1989a): 'Why Does Stock Market Volatility Change Over Time?', Journal of Finance, 44, 1115-1153. 
37. Schwert, G. William (1989b): 'Business Cycles, Financial Crises and Stock Volatility', NBER Working Paper no. 2957.

38. Worrell, DeLisle and Hyginus Leon (2001): 'Price Volatility and Financial Instability', IMF Working Paper No. 01/ 60. 